CONFERENCE PAPER

\title{
TRYING TO SOLVE THE FORMALIN ISSUE IN THE VETERINARY ANATOMY TEACHING (FACULTY OF VETERINARY MEDICINE, ZAGREB)
}

\section{Tajana Trbojević Vukičević¹*, Silvija Jelačič², Kim Korpes ${ }^{1}$, Magdalena Kolenc ${ }^{1}$, Martina Đuras ${ }^{1}$}

${ }^{1}$ Department of Anatomy, Histology and Embryology, Faculty of Veterinary Medicine, University of Zagreb, Zagreb, Croatia

${ }^{2}$ Veterinary practice Pet-plus, Karlovac, Croatia

*Corresponding author:

Prof. Dr. Tajana Trbojević Vukičević* Department of Anatomy, Histology and Embryology, Faculty of Veterinary Medicine, University of Zagreb

Zagreb, Croatia

Address: Heinzelova 55

Phone: ++38512390241

E-mail: tajana@vef.unizg.hr

\begin{abstract}
The Department of Anatomy, Histology and Embryology of the Faculty of Veterinary Medicine, University of Zagreb has been established in 1919 and there have been several changes in syllabuses and titles of the anatomy course. However, what has remained unchanged over all these decades is the use of formaldehyde solutions (4 or $10 \%$ concentrations) to preserve anatomical specimens for teaching purposes. Due to the proven toxic, allergic and carcinogenic characteristics of formalin, there is a global trend to reduce and completely eliminate formalin as a fixative in anatomy courses.

With this aim, we started looking for alternative methods for fixating anatomical specimens. Since 2019, we have included anatomical specimens impregnated with polyethylene glycol and fresh carcasses, or body parts in anatomy courses. We have managed to reduce the use of formalized specimens by $100 \%$ for courses in Anatomy with Organogenesis of Domestic Animals I and III for the study program in English, and by 50\% for the same courses in Croatian. Likewise, a 50\% reduction was performed in Anatomy II in both study programs. Permanent dry specimens of hollow organs are also used in practicals. The storage of fresh specimens in $1.08 \%$ solution of acetic acid is still in experimental phase, but so far it has proved to be an extremely good alternative, safe for usage, cheap and suitable over a short period time in the anatomy course. All these changes caused harmless removal of worn-out and unnecessary formalized specimens and the adaptation of the Department's facilities.
\end{abstract}

Keywords: formalized anatomical specimens, polyethylene glycol, acetic acid solution 


\section{INTRODUCTION}

The Department of Anatomy, Histology and Embryology at the Faculty of Veterinary Medicine, University of Zagreb was established in 1919. There have been several changes in syllabuses and titles of the anatomy course. But, since 2007 the domestic animal anatomy has been taught in three obligatory subjects with a total of 53 hours of lectures and 227 hours of practicals. In the first semester, the course Anatomy with Organogenesis of Domestic Animals I has 18 hours of lectures and 64 hours of practicals and beside the introduction to the veterinary anatomy nomenclature, the main content of this course is gross anatomy and development of the thoracic and pelvic limbs of domestic mammals. In the second semester, the Anatomy with Organogenesis of Domestic Animals II has 20 hours of lectures and 100 hours of practicals, and presents the gross anatomy of major anatomical structures of the trunk and the viscera of domestic mammals with the embryonic development of organs and organ systems. The course in the third semester is Anatomy with Organogenesis of Domestic Animals III with 15 hours of lectures and 63 hours of practicals. This course presents the gross anatomy and development of the head and neck of domestic mammals and basic gross anatomy of domestic birds. Since the academic year 2016/2017, part of the staff of the Department has been participating in teaching courses in English with the same syllabuses.

One of the learning aims for all these subjects is to gain dissection skills. Research has shown that despite many technological possibilities of today, learning on classical specimens is still an irreplaceable method of learning anatomy (Aziz et al., 2002; Hasan et al., 2010). Through dissection practicals, students are learning actively and acquire practical and surgical skills. They also develop a professional way of thinking. Touching different anatomical structures stimulates the development of a sense of spatial perception and the emergence of photographic memory. While learning on anatomical specimens during their education, the possibility of professional error in future veterinary career is reduced (Oehme, 2016). Over the years, a number of successful or less successful methods of conserving anatomical structures, organs, and entire animal carcasses have been developed. The most common method is usage of $10 \%$ aqueous formaldehyde solution. Other methods include the use of glycerol, alcohol, and phenol (Silva et al., 2007). Formaldehyde is a substance with great bactericidal, fungicidal and insecticidal properties. Despite its excellent tissue preservation ability (Figure 1.) and frequent

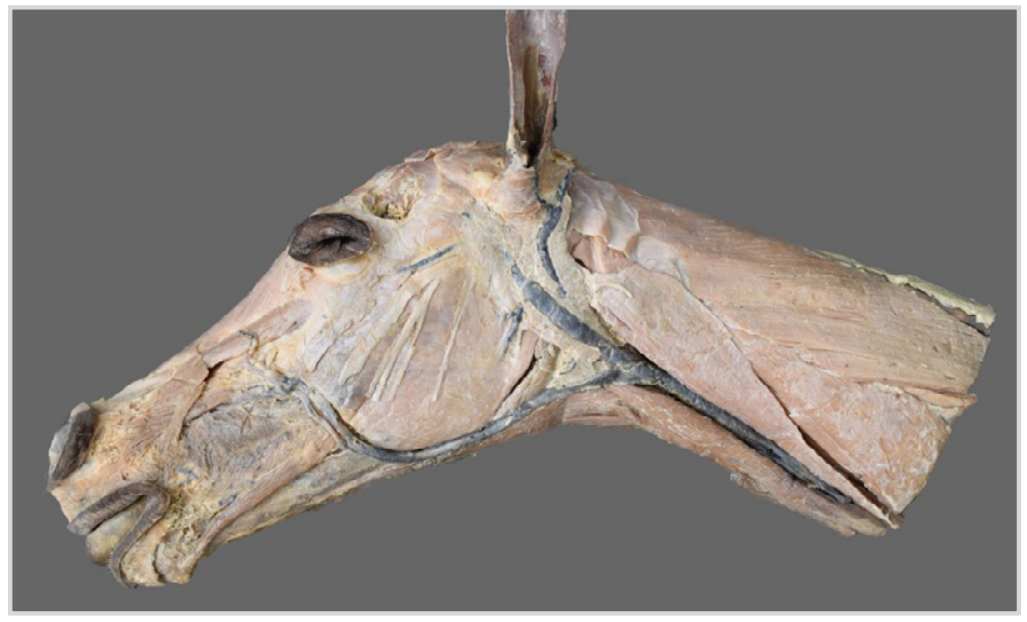

Figure 1 Horse head half specimen preserved with formalin 
use, there is a significant health risk involved in handling formalin-treated specimens.

Formalin has toxic, allergic and carcinogenic characteristics. It enters the body by inhalation, absorption through the skin or fluids and causes irritation of the mucous membranes of the upper respiratory tract and eyes. It can also lead to leukaemia, nasopharyngeal tumours, abortion, congenital malformations, skin irritations and neurophysiological disorders (Elshaer and Mahmoud, 2017; Tamayo-Arango and GarzónAlzate, 2018). According to Viegas et al. (2010), students, anatomy teachers and other staff are exposed to the high concentrations of formalin in laboratories and other rooms where anatomy classes take place.

Due to toxicity and in order to reduce and eliminate formalin as a fixative from the use, several alternative methods of organ preservation have been developed. According to the recommendation of The European Association of Establishments for Veterinary Education - EAEVE, it is necessary to replace formalin with one of the non-toxic alternative methods. The aim is to develop new preservation methods that will enable permanent preservation of the anatomical specimens in ambient conditions without significant changes in the appearance and flexibility of the specimens, absence of unpleasant odour and preservation of natural tissue colour (Lombardero et al., 2017).

\section{MATERIAL AND METHODS}

The aim of this paper is to systematically describe the methods of conservation of animal material used today in the study of veterinary anatomy and education of future veterinarians, with special reference to the advantages and disadvantages of methods that are in use today at the Department of Anatomy, Histology and Embryology, Faculty of Veterinary Medicine, University of Zagreb and a critical assessment of the introduction of new, less harmful ways of preserving anatomical specimens.

\section{Impregnation with polyethylene glycol}

Numerous disadvantages in the formalin preservation of anatomical specimens prompted the search for an alternative method of preserving carcasses and organs for the teaching purposes. After analysis of the existing equipment and available financial resources, in 2018 we concluded that part of the anatomical specimens required for teaching will be preserved with polyethylene glycol and offered experimentally to teachers and students during practicals.

The process of impregnation with polyethylene glycol allows the conversion of fresh or wet into dry specimens (Oehme, 2016). In this method of preservation, tissue fluids are withdrawn from the biological material by the process of diffusion and replaced with polyethylene glycol (PEG). PEG is a liquid or solid colourless polymer which, as the molecular weight increases, becomes harder and the hygroscopic effect decreases. (Geymayer and Gütebier, 1979; Prescher, 1986).

Before the impregnation procedure, it is necessary to prepare anatomical specimens. Hollow organs should be emptied and rinsed well, nerves, blood vessels, and lymph nodes should be carefully dissected. Then, the specimens should be cleaned 
with $20 \%$ hydrogen peroxide. This method was described by Steinmann (1982), who suggested the prepared specimens are immersed in a $2-5 \%$ formalin solution for several days or weeks, depending on the size of the specimen. The fixative is considered to penetrate the tissue at a rate of $1 \mathrm{~cm}$ per day of fixation and therefore the required process time can be determined. In order to achieve better fixation of larger specimens, it is possible to inject a formaldehyde solution into the tissue. After the fixation process, the specimen is transferred to a wire container made of stainless steel which is attached to a vacuum container and immersed in a solution of low molecular weight polyethylene glycol (PEG 400). In the process of preserving hollow organs, it is necessary to remove all air and residual fixative from the cavities before immersion in the PEG solution. In a vacuum tank, the specimens are exposed to a temperature of $50^{\circ} \mathrm{C}$ and a low air pressure of 15 millibars. PEG solution should be changed several times during the impregnation process. After completion of the process, the specimen is removed from the tank and the excess solution is removed from the tissue surface and dried for several days on filter paper in a room with no exposure to direct sunlight. At the end of drying, the specimens look native to the natural tissue and are ready for use.

Due to the fact that polyethylene glycol does not polymerize during the impregnation process, the obtained specimens are soft and flexible, which allows mobility without damaging them. For these reasons, this method is very suitable for preserving joint specimens. The entire production process can be carried out in a period of two weeks (König et al., 2013).

The PEG impregnation process was performed

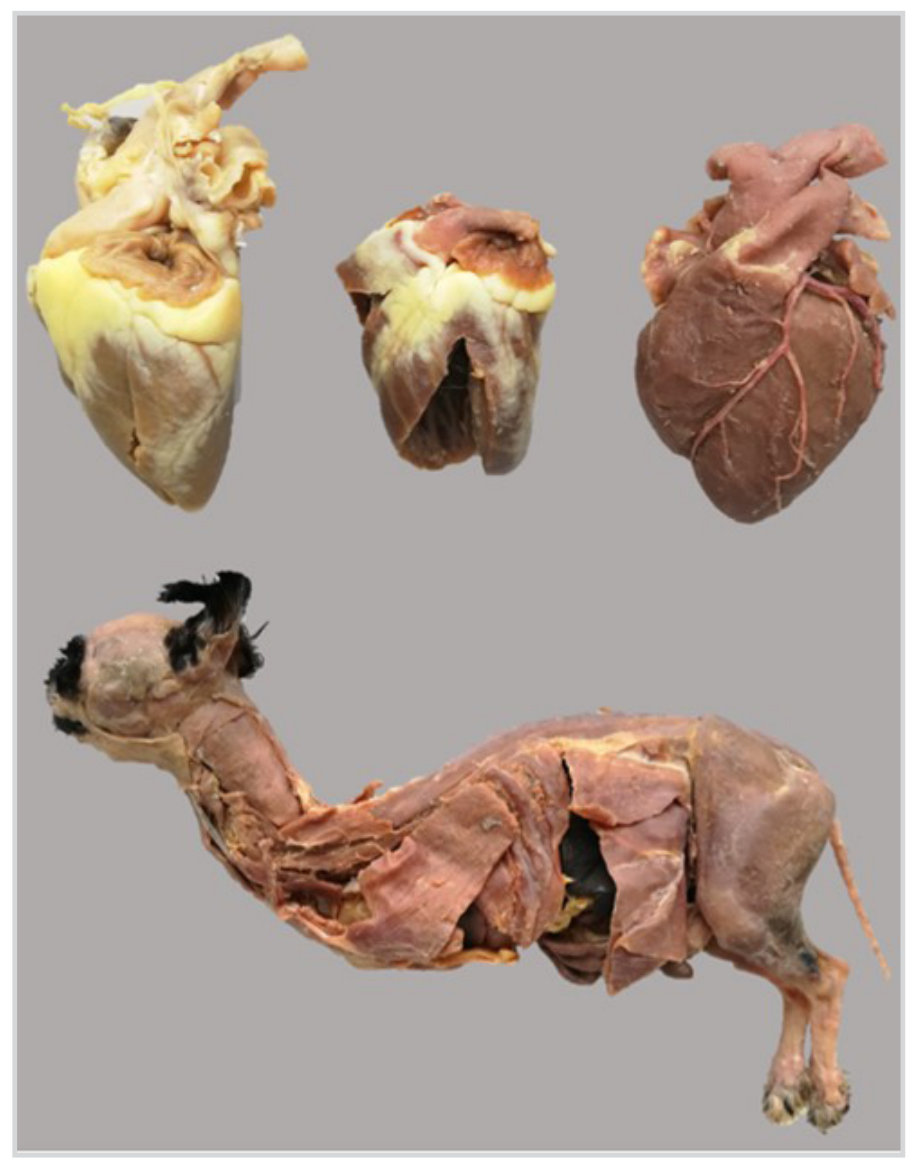

Figure 2 Polyethylene glycol impregnated specimens. Upper row: sheep hearts; lower row: dog carcass without thoracic limbs. 

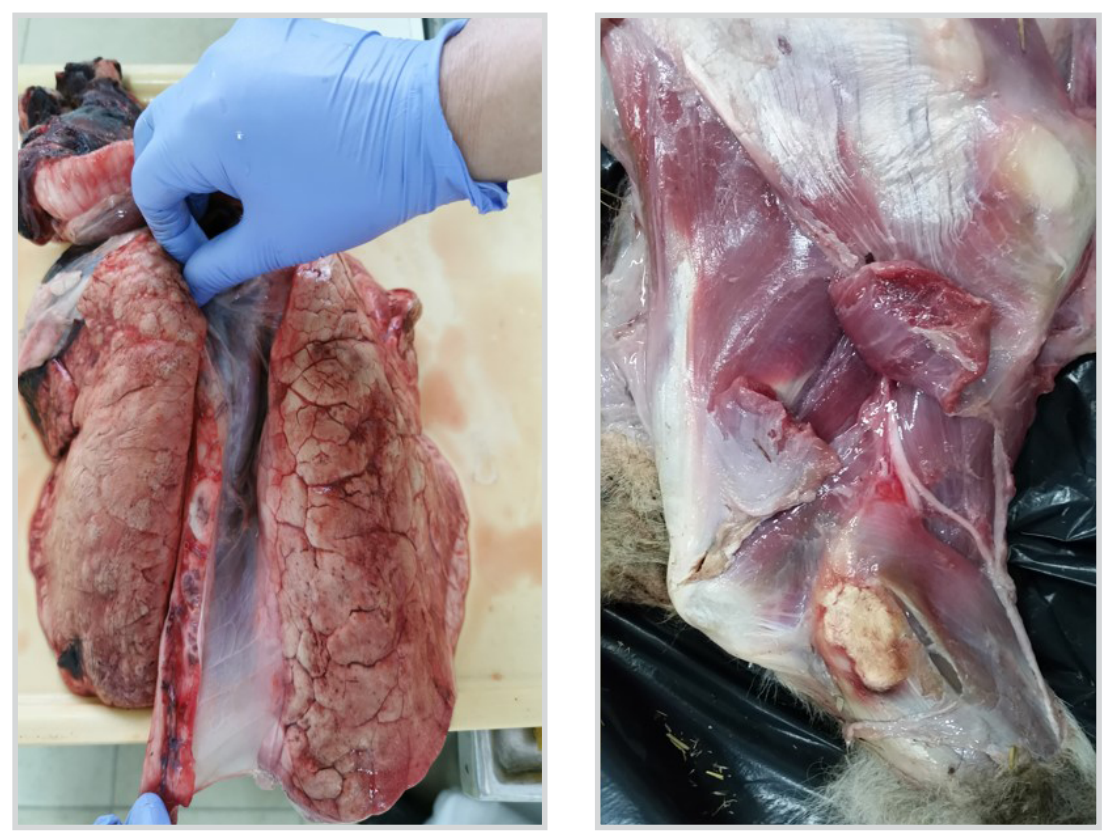

\section{Figure 3 Fresh}

specimens. Left: pig's lungs; right: dog's pelvic limb. at the Institute of Morphology, University of Veterinary Medicine Vienna and financed from the project Development of standards for occupations and qualifications and improvement of the integrated undergraduate and graduate studies of veterinary medicine at the Faculty of Veterinary Medicine Zagreb by European Social Fund (ESF) through the Ministry of Science and Education (MSE), Republic of Croatia (Đuras, 2020).

\section{RESULTS}

At the Department of Anatomy, Histology and Embryology, Faculty of Veterinary Medicine, University of Zagreb, the first anatomical specimens impregnated with polyethylene glycol were used in courses during the academic year $2019 / 2020$. For this purpose, five thoracic and five pelvic limbs of dogs and one thoracic limb of a cat were first fixed with $10 \%$ formalin and thoroughly anatomically dissected at our Department. In November 2020 the whole carcass of a dog and cat, specimens of eight head halves and 26 specimens of internal organs of various animal species, were finished and used during the last academic year (Figure 2).

\section{Fresh specimens}

Since 2019, we have included fresh carcasses or body parts in anatomy courses. These specimens are most similar to living tissue in terms of organoleptic properties, and for that reason, they are an ideal material for learning. However, the procurement of fresh specimens is often difficult. They can be used only a few days due to the development of post-mortem processes of autolysis and putrefaction, there is a risk of infection with microorganisms when handling specimens and the ethical use of such specimens is questionable due to short shelf life and consequent need for new preparations (Oehme, 2016). In the academic year 2019/2020 at the Department of Anatomy, Histology and Embryology, horse, bovine and pig internal organs (lungs, hearts, larynx, genital organs), heads, thoracic and pelvic limbs, and chicken carcasses were donated or purchased from commercial suppliers for teaching purposes (Figure 3). These specimens were stored in the freezing chamber at $-20^{\circ} \mathrm{C}$ and were used for the dissection, either for students' practicals or for future impregnation with PEG (Đuras, 2020). 


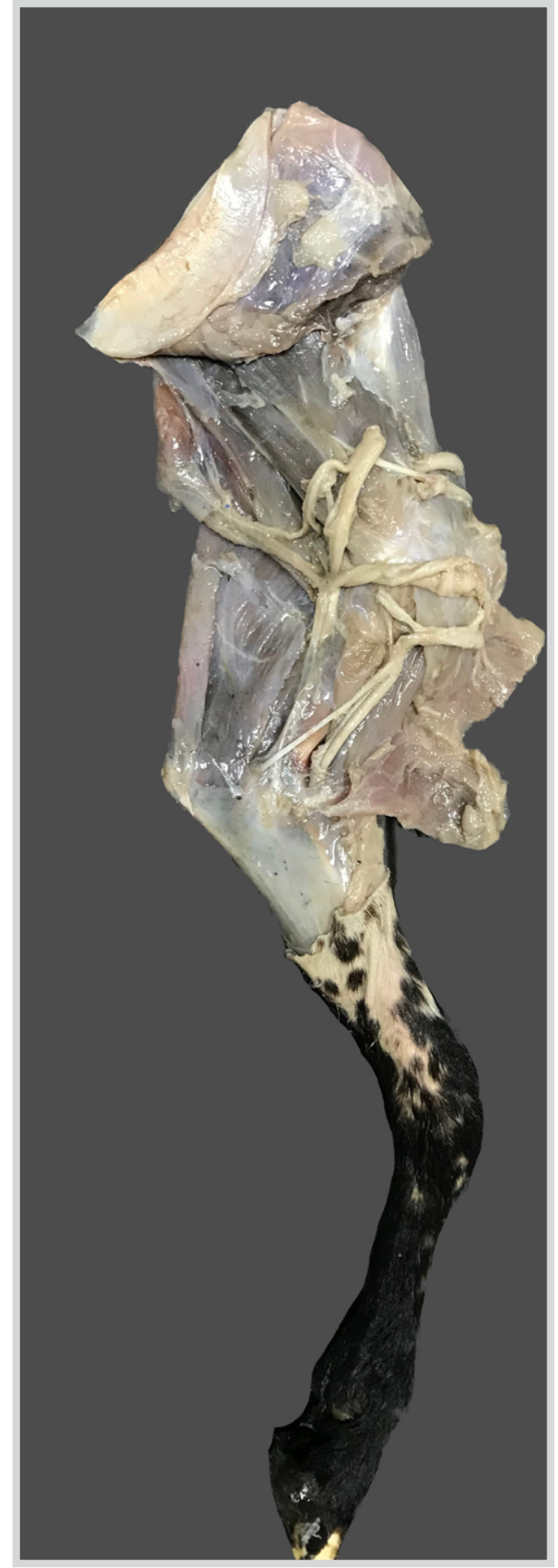

Figure 4 Small ruminant's thoracic limb. Preserved with acetic acid.

\section{Preservation with acetic acid}

Preservation of anatomical specimens in acetic acid solution has been so far sparsely described in the available literature. Acetic acid solution has been used sporadically in medicine for the last 6 000 years in wound disinfection, treatment and prophylaxis of various diseases such as plague, urinary tract, thoracic cavity and ear infections, and is generally considered a good disinfectant, especially in eliminating bacteria (Halstead et al.,2015). Vinegar, whose dominant ingredient is acetic acid, has been used for centuries in food preservation processes as an inhibitor of the growth of pathogenic microorganisms in food. Numerous studies have proven the effectiveness of vinegar in inhibiting pathogenic microorganisms in fresh fruits and vegetables (Budak et al., 2014).

At the Department of Anatomy, Histology and Embryology, Faculty of Veterinary Medicine in Zagreb, during 2019 we started an experiment with acetic acid. A $1.08 \%$ solution of acetic acid was obtained by mixing 3 liters of alcohol vinegar (9\%) with 22 liters of tap water. Pig and cattle hearts, pig and goat thoracic limbs, pig and horse head halves were first dissected fresh, immersed in the acetic acid solution and stored at $+4{ }^{\circ} \mathrm{C}$ until the next practicals. Then, they were used again during the dissection and so on until the end of the class (Figure 4). The specimens were checked at day 5 and 10 for colour, flexibility, consistency and odour. At day 5, all the specimens became pale on the surface, softer in consistency, but still firm and elastic enough for manipulation. Deeper tissues retained almost natural colour and harder consistency, but without the characteristic rotten odour. All specimens were suitable for further dissection. At day 10, all the specimens maintained elasticity, though paler and softer with a slight vinegar odour and suitable for dissection (Trbojević Vukičević at al., 2021). 


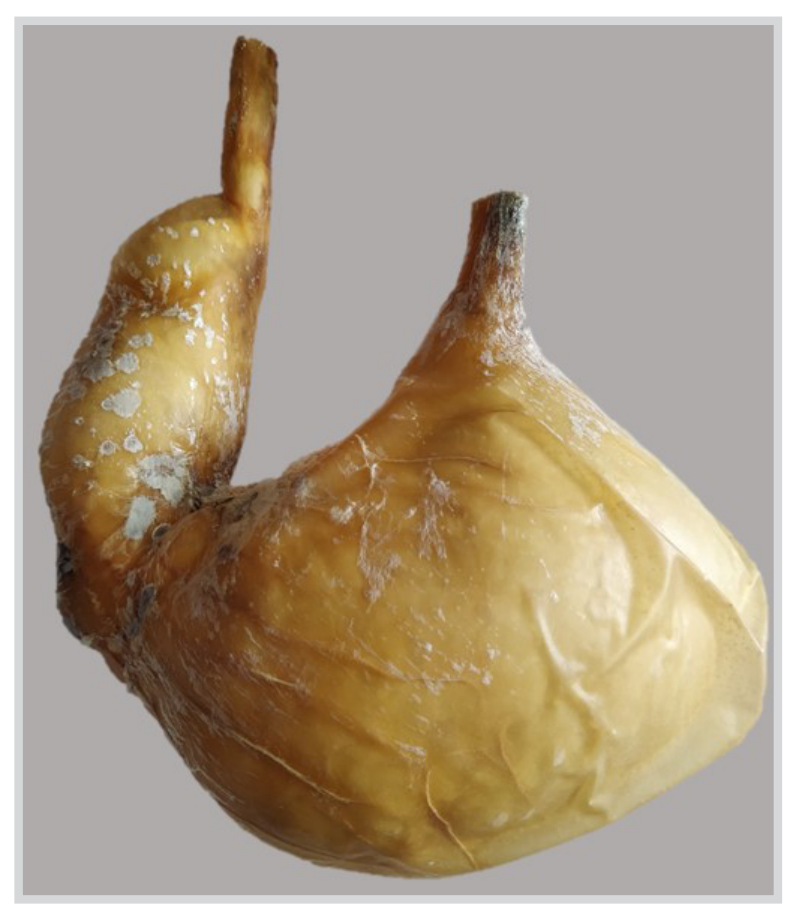

Figure 5 Dry specimen of dog's stomach

\section{Dry specimens of hollow organs}

In the academic year 2019/2020 for the Anatomy with Organogenesis of Domestic Animals II practicals, permanent specimens of pig sheep and dog stomach were made by the method developed in the Department of Anatomy of the Faculty of Veterinary Medicine in Sarajevo. The method has several steps. The first step consists of rinsing the organs with water and removing excess tissue. The hollow organ is then immersed in a solution of alum and after placed in an anatomical position and fixed to a drying pump. The length of the drying period depends on the size of the hollow organ. After drying, the specimen is filled with polyurethane foam to one third of the volume of the organ cavity and varnished with colourless varnish (Figure 5). This process results in the hollow organ specimen that can last for years (Budinšćak, 2020).

\section{DISCUSSION AND CONCLUSION}

Depending on the method of use and the requirements that the anatomical specimen must satisfy, there are different specialized methods of fixation and preservation. The choice of method is conditioned primarily by animal tissue, and by the requisite in teaching, space and equipment, professional staff and financial resources available for making anatomical specimens. All these factors must be considered when choosing a method of preservation (Jelačić, 2021).

At the Department of Anatomy, Histology and Embryology of the Faculty of Veterinary Medicine, University of Zagreb, several types of anatomical specimens are used for the domestic animal anatomy teaching. For studying the skeletal system, bone specimens made by methods of maceration, cooking, degreasing and bleaching are used. Other organ systems are studied by a section of whole carcasses or individual organs.

The method of wet conservation with formalin has been in use since the founding of the Department in 1919. Formalin has a lot of positive properties due to which it is often used in tissue preservation processes. It has excellent antiseptic properties by which it prevents entrance of putrefactive microorganisms into the tissue and ensures the preservation of fine tissue structures (Hayashi et al., 2014). Formaldehyde has a proven detrimental effect on human health manifested by skin, eye and respiratory system irritations, headache, and after prolonged exposure vertigo and epistaxis (Wantke et al., 2000; Brenner, 2014). The severity of the symptoms depends on the length of exposure time and the concentration of formalin in the room. In addition to irritating and allergic properties, formalin is classified in the group of carcinogenic substances. The International Agency for Research on Cancer (IARC) in 2006 classified formalin as a group 1 human carcinogen due to its proven 
carcinogenic properties for humans and animals. Risk groups sensitive to the effects of formaldehyde include students majoring in medicine and employees of anatomical departments. According to numerous studies, evaporation of formaldehyde from formalized specimens in dissection halls can produce very high concentrations of harmful substances in the air, which may be due to poor ventilation in dissection rooms, use of high concentrations of formaldehyde in preservative solutions, improper handling of specimens, leakage of formalin from anatomical specimens in poor condition, lack of strict rules for the use and handling those specimens, and neglect of the serious consequences of formalin exposure (Elshaer and Mahmoud, 2017).

Due to the listed reasons, there is a global trend to reduce and completely eliminate formalin as a fixative in anatomy courses. With this aim, we started looking for alternative methods for fixating anatomical specimens. Since 2019, we have included anatomical specimens impregnated with polyethylene glycol (PEG) and fresh carcasses or body parts in anatomy courses. Polyethylene glycol (PEG) impregnation has been in use since the 1970s, and is still widely used today for its reasonable price and quality specimens (Racek, 1974; Geymayer and Gütebier, 1979; Steinmann, 1982). The method is simple and relatively cheap, namely a container with 220 litters of polyethylene glycol costs about 500 euros and can be recycled after use by heating to $90{ }^{\circ} \mathrm{C}$ (König et al., 2013). The process is short and the obtained specimens are not toxic, there is no risk to health when handling them and there is a possibility of achieving different consistencies of the specimens by applying polyethylene glycol of different molecular weight. The obtained specimens are stable, resistant to the bacteria, molds and insects, and their size, consistency and flexibility correspond to natural tissue. They can be painted using water or oil paints. Specimens are very easy to store in plastic bags and then in plastic boxes, where it is possible to reduce the volume of the hollow organs specimens by expelling air from the cavities. Properly stored in a dry and clean place, anatomical specimens impregnated with PEG have an almost unlimited shelf life and can be recycled after long-term use (Prescher, 1986; Uhlmann, 1991).

The plan for the future in the Department of Anatomy, Histology and Embryology, Faculty of Veterinary Medicine, University of Zagreb is the complete exclusion of formalin from teaching, which is planned to be achieved by a further combination of impregnated and fresh specimens. Students will get acquainted with the anatomical structure of the body and organs on permanent, impregnated or dry hollow organs specimens, after which they will access the dissection on fresh specimens (Bastiančić et al., 2020). In order to improve the longevity of fresh specimens and reduce their total number during each semester, between practicals fresh organs or body parts are stored in an acetic acid solution. The storage of fresh specimens in $1.08 \%$ solution of acetic acid is still in experimental phase, but so far it has proved to be an extremely good alternative, safe for usage, cheap and suitable over a short period time in the anatomy course. Storage of those specimens does not require specialized accessories and maintenance of the specimens is not demanding (Trbojević Vukičević et al., 2021).

In the academic year 2020/2021, by using a combination of PEG and fresh/acetic acid preserved specimens, we have managed to reduce the use of formalized specimens by $100 \%$ for courses Anatomy with Organogenesis of Domestic Animals I and III and for the study program in English, and by $50 \%$ for the same courses 
in Croatian. Likewise, a $50 \%$ reduction was performed in Anatomy II in both study programs.

By implementing this method of teaching, students learn in non-toxic conditions, and the knowledge acquired on permanent, previously dissected specimens is applied during an independent section on fresh specimens. It will be possible to achieve such a planned method in $100 \%$ of teaching when a larger number of permanent specimens is achieved (Bastiančić et al., 2020).

In order to achieve the plan of completely excluding formalin from classes, $1,200 \mathrm{~kg}$ of worn-out and unnecessary anatomical specimens preserved by formalin and 2,300 kg of formalin in which these preparations were stored, was harmlessly removed (Đuras, 2020). Also, the tanks for storing anatomical specimens, whose total volume was about $7 \mathrm{~m}^{3}$, and which, due to permeability, were the cause of constant evaporation of formaldehyde, were demolished. A cold chamber has been installed in place of the collapsed tanks, and it is used to store fresh or acetic acid- preserved specimens at $+4^{\circ} \mathrm{C}$ and enable their use for several days.

The plastination of anatomy specimens and 3D anatomy models reduced the number of animals used in the anatomy study. They are important in

\section{REFERENCES}

Aziz MA, Mckenzie JC, Wilson JS, Cowie RJ, Ayeni SA, Dunn BK. 2002. The Human Cadaver in the Age of Biomedical Informatics. The Anat Rec, 269, 20 - 32.

Bastiančić L, Leiner D, Kolenc M, Kovač G, Korpes K. 2020. Put od Savske do Heinzelove ulice - osvrt na nastavu Zavoda. Ljetopis Veterinarskog fakulteta Sveučilišta u Zagrebu za ak. god. 2019./2020., 148-153.

Brenner E. 2014. Human body preservation - old and new techniques. J Anat, 224, 316-44. the pre-dissection stage of teaching and learning. However, plastinated specimens cannot replace the animal carcass, body parts and organs from the teaching process. They are important for the acquirement of the knowledge on the topography and for the development of dissection skills.

\section{ACKNOWLEDGEMENTS}

This article was presented at the Conference on humane innovations in education Ibrahim Arnautović, 12th to 13th November 2021, Sarajevo, Bosnia and Herzegovina.

The presentation was supported by the funding from the project Development of standards for occupations and qualifications and improvement of the integrated undergraduate and graduate studies of veterinary medicine at the Faculty of Veterinary Medicine Zagreb financed by European Social Fund (ESF) through the Ministry of Science and Education (MSE), Republic of Croatia.

\section{CONFLICT OF INTEREST}

The authors declared that there is no conflict of interest.
Budak NH, Aykin E, Seydim AC, Greene AK, Guzel-Seydim ZB. 2014. Functional Properties of Vinegar. J Food Sci, 79, 757-764.

Budinšćak Z. 2020. Osvrt na preparatorsku jedinicu Zavoda za anatomiju, histologiju I embriologiju: izrada trajnih preparata I uvođenje novih metoda u konzerviranju I nastavi. Ljetopis Veterinarskog fakulteta Sveučilišta u Zagrebu za ak. god. 2019./2020., 155-157.

Đuras M. 2020. Nastavna aktivnost Zavoda za anatomiju, histologiju I embriologiju. Ljetopis Veterinarskog fakulteta Sveučilišta u Zagrebu za ak. god. 2019./2020., 43-48. 
Elshaer NSM, Mahmoud MAE. 2017. Toxic effects of formalin-treated cadaver on medical students, staff members, and workers in the Alexandria Faculty of Medicine. Alexandria J Med, 53, 337-343.

Geymayer P, Gütebier T. 1979. Polyethylen glycole ihre Chemie und Anwendung in der Präparationstehnik. Der Präparator, 25, 65 - 70 .

Halstead FD, Rauf M, Moiemen NS, Bamford A, Wearn CM, Fraise AP, et al. 2015. The Antibacterial Activity of Acetic Acid against BiofilmProducing Pathogens of Relevance to Burns Patients. PLoS ONE 10(9):e0136190. doi: 10.1371/ journal.pone.0136190.

Hasan T, Ageely H, Hasan D. 2010. The role of traditional dissection in medical education. Education in Medicine Journal, 2, 30-34.

Hayashi S, Homma H, Naito M, Oda J, Nishiyamat, Kawamoto A, et al. 2014. Saturated Salt Solution Method: A Useful Cadaver Embalming for Surgical Skills Training. Medicine 93, 1-10. DOI: 10.1097/MD.0000000000000196

Jelačić S. 2021. Pregled metod konzerviranja životinjskih preparata u veterinarskoj anatomiji. Graduate thesis, Sveučilište u Zagrebu, Veterinarski fakultet, Zagreb, Croatia.

König HE, Probst A, Dier H, Sora MC. 2013. Production of anatomical specimens for teaching practice in veterinary anatomy by means of polyethylene glycol (peg) impregnation a comparison with the method of plastination. Chilean J Agric Anim Sci, ex Agro-Ciencia 29, 59-64.

Lombardero M, Yllera MM, Costa-E-Silva A, Oliveira MJ, Ferreira PG. 2017. Saturated salt solution: a further step to a formaldehyde-free embalming method for veterinary gross anatomy. J Anat, 231, 309-317.

Oehme Y. 2016. Konzervierungs methoden in der tieranatomie. PhD, Der Tierärztlichen Fakultät der Ludwig-MaximiliansUniversität München, München, Germany.

Prescher A. 1986. Eine weitere Methode zur farberhaltenden Organkonservierung. Der Präparator, 32, 361-364.
Racek M. 1974. Weitere Vereinfachung der Paraffinierungs method durch Verwendung von Polyäthylenglycol. Der Präparator, 20, 48-50.

Silva RM, Matera GJM, Ribeiro AACM. 2007. New Alternative Methods to Teach Surgical Techniques for Veterinary Medicine Students despite the Absence of Living Animals. Is that an Academic Paradox? Anat Histol Embryol, 36, 220-224.

Steinmann WF. 1982. Makroskopische Präparations methoden in der Medizin. Stuttgart, New York: ThiemeVerlag, 171-247.

Tamayo-Arango L, Garzón-Alzate A. 2018. Preservation of animal cadavers with a formaldehyde-free solution for gross anatomy. J Morphological Sci, 35, 136-141.

Trbojević Vukičević T, Jelačić S, Korpes K, Kolenc M, Đuras M. 2021. The acetic acid experiment - an alternative solution for anatomy specimen preservation?, in: Abstract Book - Poster Sessios of the 33rd Congress of the European Association of Veterinary Anatomists. p. 111.

Uhlmann K. 1991. Die Konservierung anatomischer Studienpräparate mit Polyethylenglykol 400. Langzeiterfahrungen und Vorstellung eines neuen, vereinfachten Verfahrens zur forcierten PEG-Imprägnation durch Luftentfeuchtung bei Normaldruck. Der Präparator, 37, 19-22.

Viegas S, Ladeira C, Nunes C, Malta-Vacas J, Gomez M, Brito $\mathrm{M}$, et al. 2010. Genotoxic effects in occupational exposure to formaldehyde: A study in anatomy and pathology laboratories and formaldehyde-resins production. J Occup Med Toxicol, 5, 25. DOI: $10.1186 / 1745-6673-5-25$

Wantke F, Focke M, Hemmer W, Bracun R, Wolf-Abdolvahab S, Götz M, et al. 2000. Exposure to formaldehyde and phenol during an anatomy dissecting course: sensitizing potency of formaldehyde in medical students. Allergy, 55, 84-87. 


\section{POKUŠAJ RJEŠAVANJA PITANJA FORMALINA U UČENJU ANATOMIJE (VETERINARSKI FAKULTET, ZAGREB)}

\section{SAŽETAK}

Zavod za anatomiju, histologiju i embriologiju Veterinarskog fakulteta Sveučilišta u Zagrebu je osnovan 1919. godine, a silabus i naziv predmeta Anatomije su promijenjeni nekoliko puta. Međutim, svih ovih decenija nije promijenjena upotreba otopina formalina (koncentracije 4 ili $10 \%$ ) kako bi se anatomski uzorci sačuvali za učenje. Zbog dokazanih toksičnih, alergijskih i karcinogenih svojstava formalina, postoji globalni trend smanjenja i potpune eliminacije formalina kao fiksatora na satima anatomije. S ovim ciljem smo počeli tražiti alternativne metode fiksiranja anatomskih uzoraka. Od 2019. godine smo na sate anatomije uključili upotrebu anatomskih uzoraka impregniranih sa polietilen glikolom, svježe leševe ili dijelove tijela. Uspjeli smo smanjiti upotrebu formalinskih uzoraka za $100 \%$ na predmetu Anatomija s organogenezom domaćih životinja I i III za studijski program na engleskom jeziku, i do $50 \%$ na istom predmetu na hrvatskom. Također smo na Anatomiji II postigli smanjenje od $50 \%$ na oba studijska programa. Na vježbama se koriste i trajni suhi uzorci šupljih organa. Čuvanje svježih uzoraka u $1.08 \%$ otopini acetatne kiseline je još uvijek u eksperimentalnoj fazi, ali se dosad pokazalo krajnje dobrom alternativom koja je sigurna za korištenje, jeftina i pogodna za kratkotrajnu upotrebu na satima anatomije. Sve ove promjene su uzrokovale bezopasno uklanjanje istrošenih i bespotrebnih formalinskih uzoraka, kao i adaptaciju prostorija Zavoda.

Ključne riječi: formalinski anatomski uzorci, polietilen glikol, otopina acetatne kiseline 